\title{
Expert System Design to Diagnos of Virus Infection Disease in Children with Certainty Factor Method
}

\author{
S. Achmadi ${ }^{1}$, A Mahmudi ${ }^{l}$, A. N. Gita ${ }^{l}$ \\ ${ }^{l}$ Informatic Engineering Dept, National Institute of Technology Malang \\ alimahmudi@gmail.com
}

\begin{abstract}
Information technology that continues to grow can be utilized in the service of human life in the world of health. Infectious disease is a disease that is quite dangerous for children. Delay in treating the disease can cause more severe disease. Such that a system that can diagnose diseases is needed. Expert systems are computer applications that try to adopt human knowledge to computer programs like an expert. Many expert systems have been developed including diagnosing stroke and others. In this study, the expert system was used as a tool to diagnose viral infectious diseases in children. In this study, we will discuss the making of expert system applications for infectious viral infections in desktop-based children using the certainty factor (CF) method. This expert system was built to diagnose tropical diseases caused by viral infections. This system provides information about diagnosis, treatment, and prevention. Methods of tracking the symptoms of each patient, need matching them with existing rules, and producing a diagnosis based on the knowledge base. Knowledge-based on this expert system was obtained from several pediatricians and reference books. This expert system application is designed based on desktop and MySQL database as data storage. The resulting output is the value of the possibility of child disease based on the symptoms that have been given by the user. The magnitude of the probability value is the result of calculations using the certainty factor method.
\end{abstract}

Keyword: expert system, artificial intelligent, children disease, certainty factor.

Paper type Research paper

\section{INTRODUCTION}

Infectious viral infections are a collection of diseases caused by viruses that easily attack children, and can be transmitted quickly through touc, air, saliva, or other intermediaries. Therefore, the symptoms caused by infectious viral infections need to be known by parents. By knowing the symptoms experienced by the child, parents can immediately find out the disease that is suffered and the prevention, so that the disease suffered by the child can be treated immediately [1].

The role of pediatricians in dealing with dangerous viral infections is necessary but often collides with the limited number of pediatricians while those that need to be handled are quite a lot. To reduce this limitation, an expert system is needed.

An expert system is one part of artificial intelligence that can mimic human reasoning processes. Expert systems can be used to help diagnose diseases, in this case, viral infections in children. The expert system diagnoses by tracking the symptoms of each patient, matching them with existing rules, and producing a diagnosis based on the knowledge base [2].

By using an expert system, it is expected to accelerate in diagnosing a type of infectious viral disease in children, so that it can be easily known the type of disease being suffered. From the description above, the authors are interested in building an application system expert diagnosis of infectious viral infections in children where the application is expected to help provide alternative solutions for parents to handle the initial symptoms of infectious viral infections in children.

Based on the problem, the formulation of the problem in this research to analyze and implement an expert system for diagnosing infectious diseases of viral infections in children. The purpose of this research to design and make an application system expert diagnosis of infectious viral infections in children whose results can show the disease suffered by children, the value of the level of trust from the results of the diagnosis, and suggestions for solutions that can be given to sufferers. 


\section{METHOD}

\section{Expert System}

An expert system is a computer-based system that uses knowledge, facts and reasoning techniques in solving problems that can usually only be solved by an expert in the field [4], [5].

In general, expert systems are systems that try to adopt human knowledge to computers that are designed to model problem-solving abilities like an expert. With this expert system, even ordinary people can solve the problem or simply find quality information that can only be obtained with the help of experts in their fields. This expert system will also be able to assist the activities of experts as assistants who are experienced and have the required knowledge.

\section{Certainty Factor Method}

Shortliffe Buchanan introduced the certainty factor in making MYCIN. Certainty factor (CF) is a clinical parameter value given by MYCIN to show the amount of trust. The equation of certainty can be written as follow.

$$
\mathrm{CF}(\mathrm{H}, \mathrm{E})=\mathrm{MB}(\mathrm{H}, \mathrm{E})-\mathrm{MD}(\mathrm{H}, \mathrm{E})
$$

Where,

- $\quad \mathrm{CF}(\mathrm{H}, \mathrm{E})$ : certainty factor from hypothesis $\mathrm{H}$ which is influenced by symptoms (evidence) E. The magnitude of $\mathrm{CF}$ ranges from -1 to 1 . The value of -1 indicates absolute distrust while value 1 shows absolute trust.

- $\mathrm{MB}(\mathrm{H}, \mathrm{E})$ : a measure of the increase in belief (a measure of increased belief) on hypothesis $\mathrm{H}$ which is affected by symptoms of $\mathrm{E}$.

- $\mathrm{MD}(\mathrm{H}, \mathrm{E})$ : a measure of the increase in disbelief (a measure of increased disbelief) against hypothesis $\mathrm{H}$ which is affected by symptoms of $\mathrm{E}$.

- $\quad \mathrm{E}=$ Evidence (event or fact).

- $\quad \mathrm{H}=$ Hypothesis (guess)

To calculate $\mathrm{CF}$ values from 1 symptom using the formula:

$$
\mathrm{CF}=\mathrm{MB}-\mathrm{MD}
$$

Whereas to calculate $\mathrm{CF}$ values with more than 1 symptom use the following equation:

$$
\begin{aligned}
& M B[h, \mathrm{e} 1 \wedge \mathrm{e} 2]=\{\mathrm{MB}[\mathrm{h}, \mathrm{e} 1]+\mathrm{MB}[\mathrm{h}, \mathrm{e} 2] *(1-\mathrm{MB}[\mathrm{h}, \mathrm{e} 1])\} \\
& M D[\mathrm{~h}, \mathrm{e} 1 \wedge \mathrm{e} 2]=\{\mathrm{MD}[\mathrm{h}, \mathrm{e} 1]+\mathrm{MD}[\mathrm{h}, \mathrm{e} 2] *(1-\mathrm{MD}[\mathrm{h}, \mathrm{e} 1])\}
\end{aligned}
$$

\section{METHODOLOGY}

A flowchart is a graphical representation of the steps that must be followed in solving a problem consisting of a set of symbols, where each symbol presents a particular activity. The flowchart begins with the reception of inputs, processing inputs and ending with the appearance of the output. The flowchart of the system to be built is shown in Figure 1.

\section{Context Diagram}

A context diagram is a flow of data that serves to describe the interrelationship of data flows between systems with outside parts. The context diagram for the system to be built is shown in Figure 2. The details of the context diagram process above are shown in Figure 3 below. 


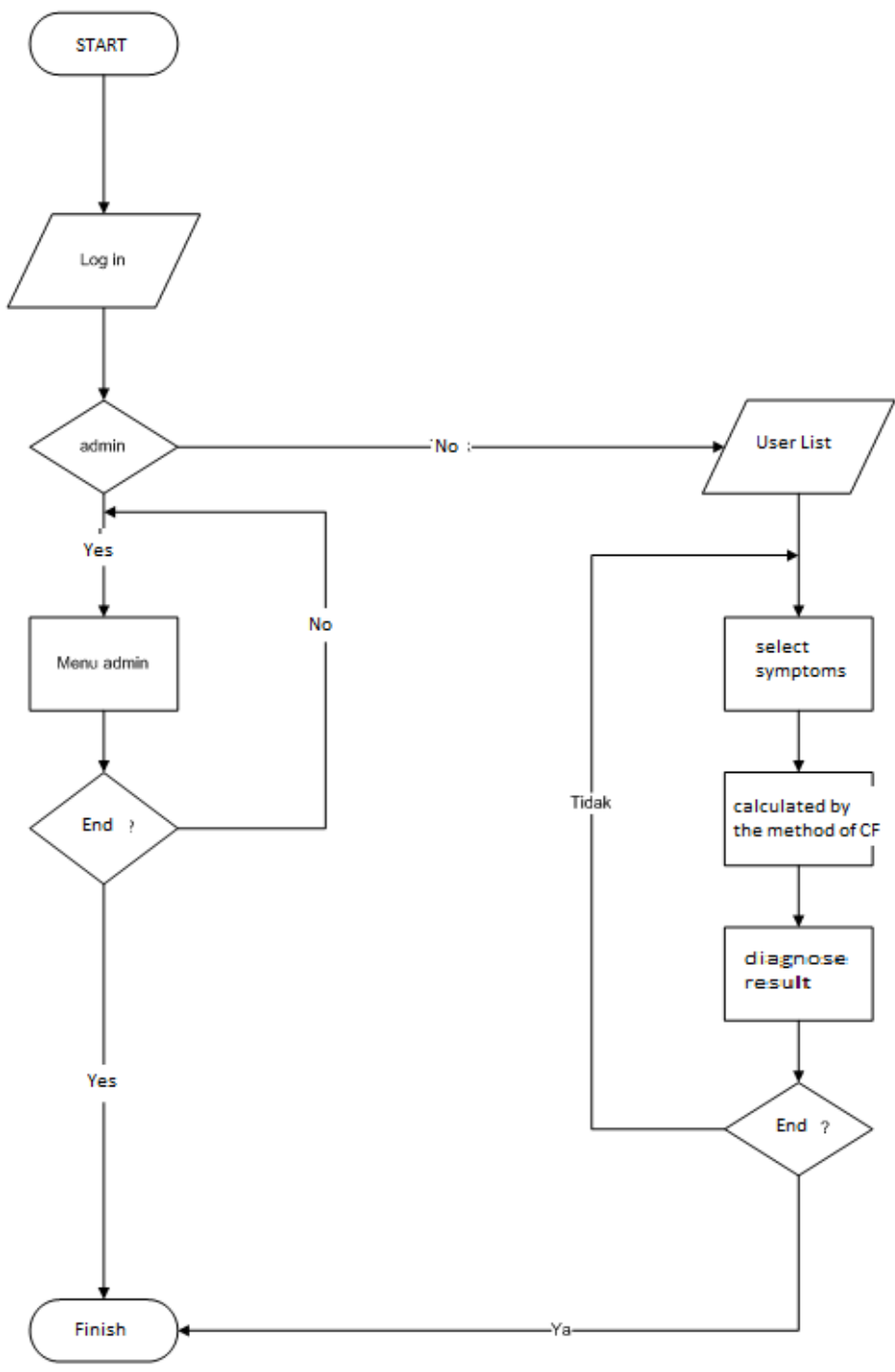

Fig. 1. Flowchart

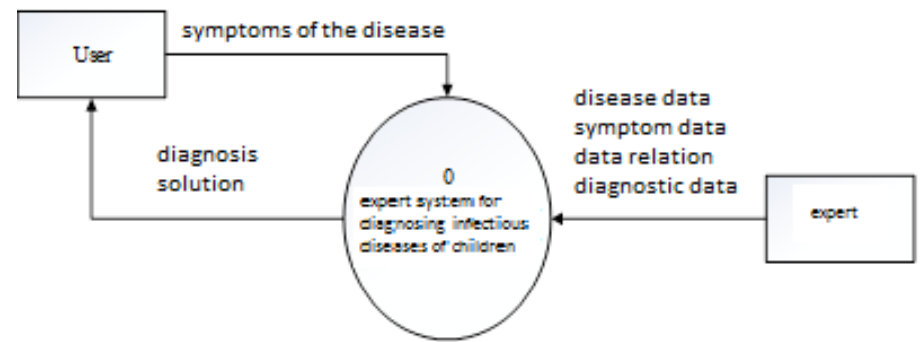

Fig. 2. Context diagram 


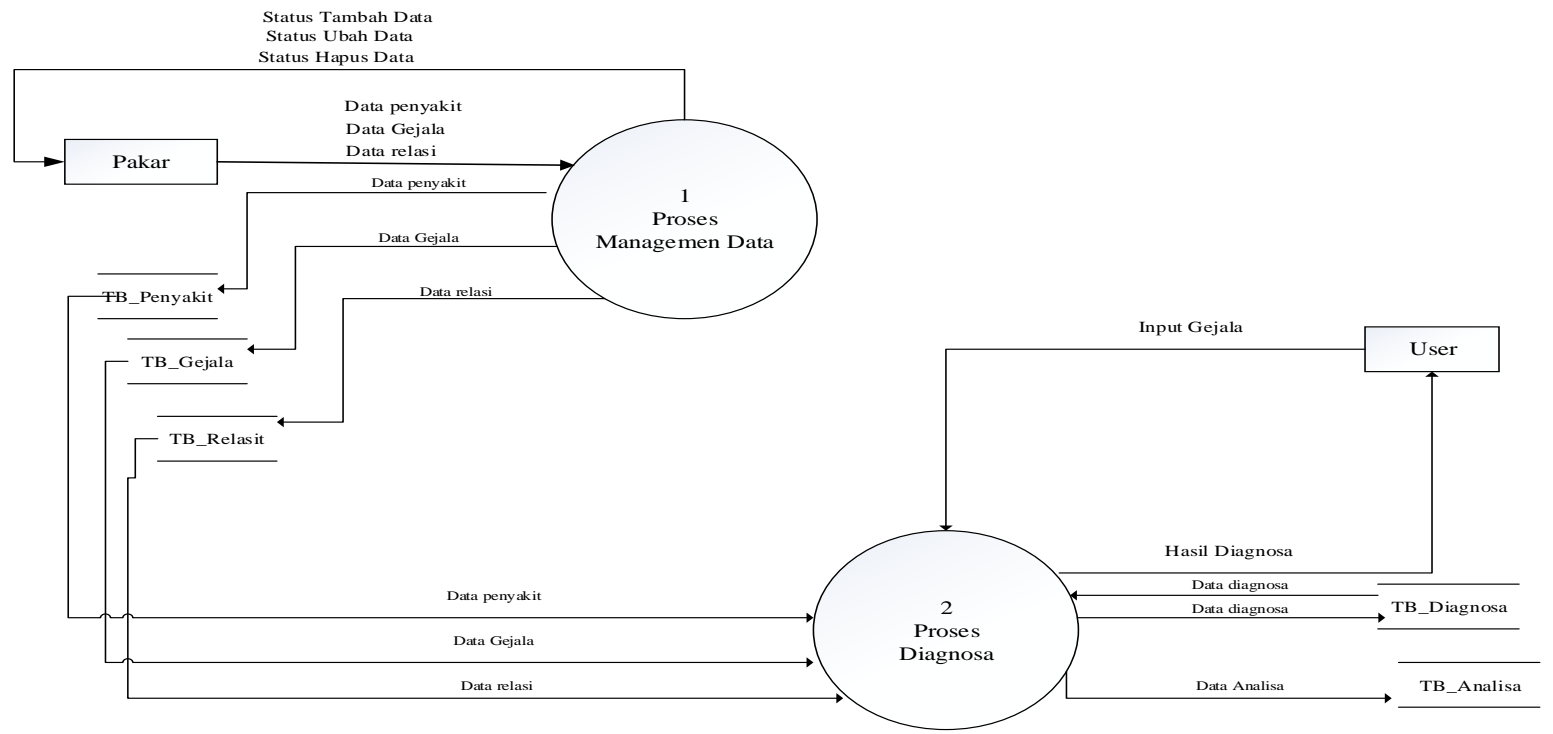

Fig. 3. DFD Level 1

\section{Results}

The application has 2 levels of users, namely users/users and admin. The menu structure for users, shown in Figure 4 and the menu structure for admin, is shown in Figure 5 below.

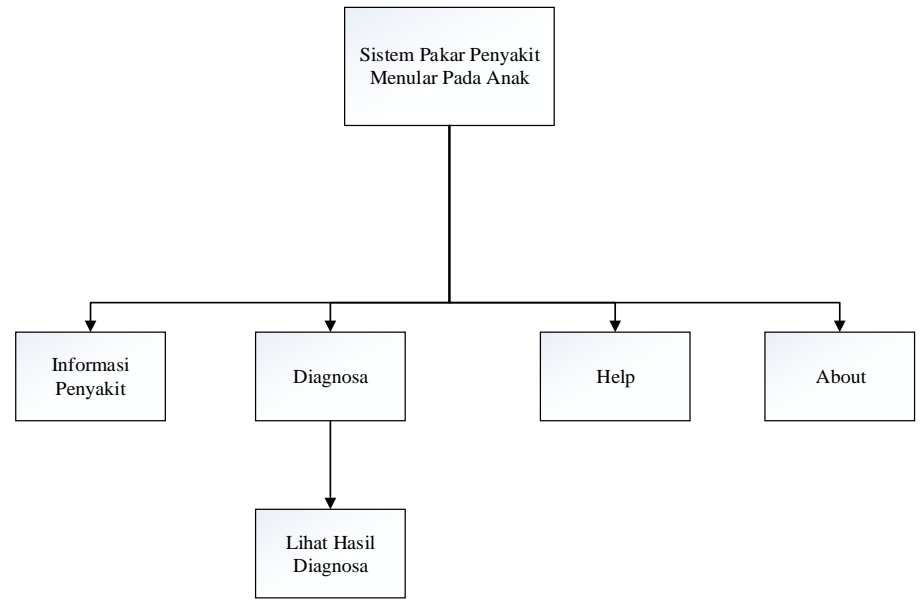

Fig. 4. User menu structure

\section{Display of User Registration Page}

This page is the user registration page. The appearance of the user registration page can be shown in Figure 6.

\section{Display of User Login Page}

The user login page is the first page that appears to display the user's menu when the system starts. The appearance of the user's Login page is shown in Figure 7.

\section{Display of Disease Information Page}

This page contains information on diseases in this expert system, including definitions and solutions for handling them. The appearance of the disease information page can be shown in Figure 8. 


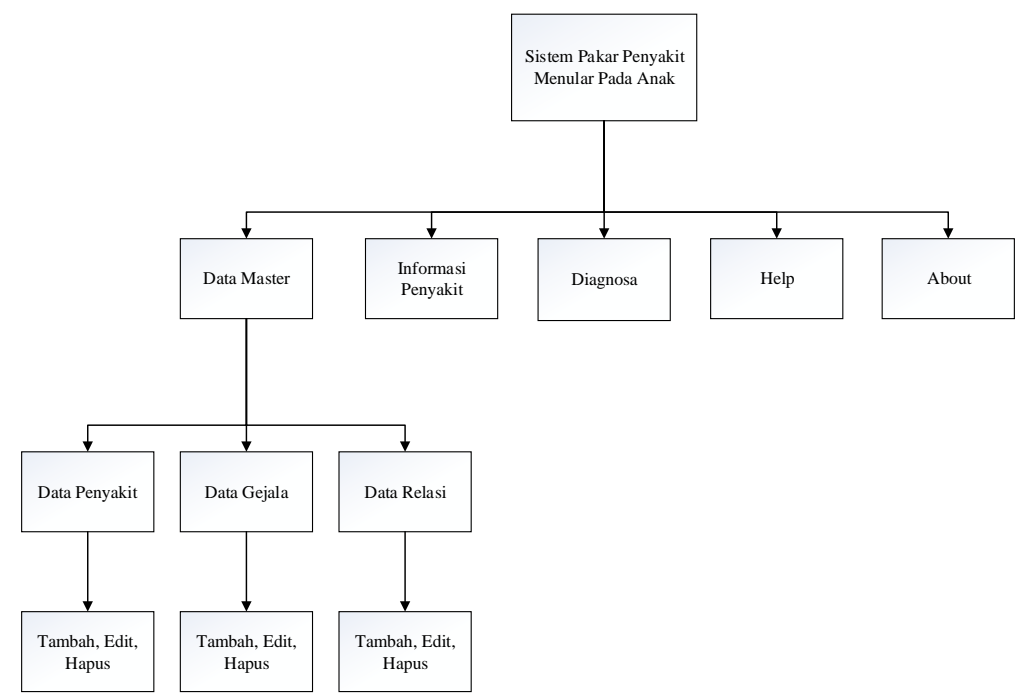

Fig. 5. Admin menu structure

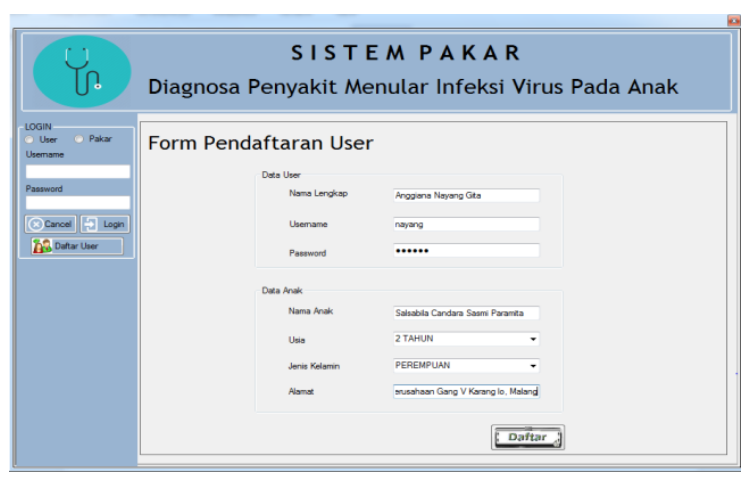

Fig. 6. User Registration Page

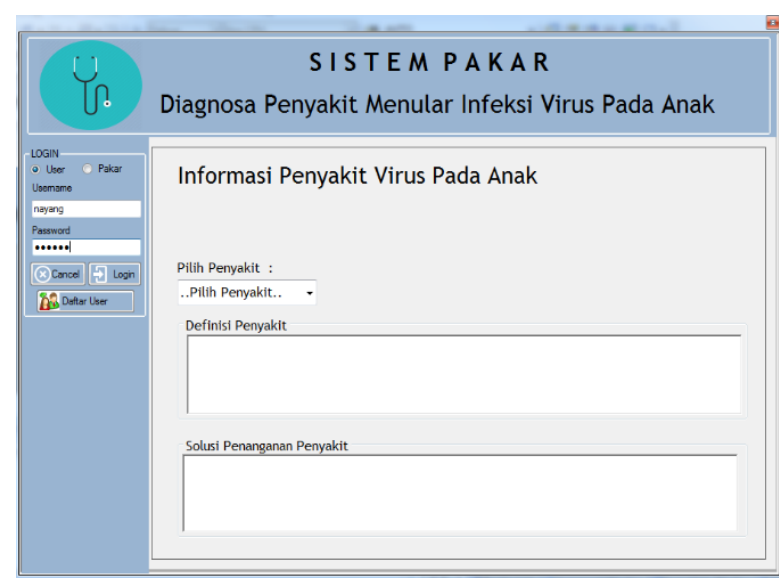

Fig. 7. User Login page 


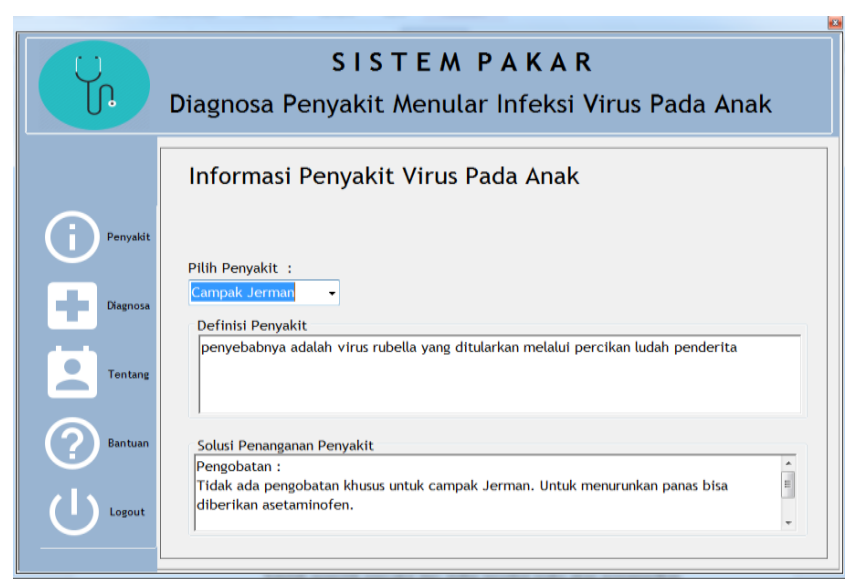

Fig. 8. Disease information page

\section{Diagnosis Page Display}

This Diagnosis page is a page that displays symptoms on a system. On this page, the user performs a diagnostic process to find out the type of disease that is experienced. The appearance of the consultation page is shown in Figure 9 and the diagnostic results are shown in Figure 10.

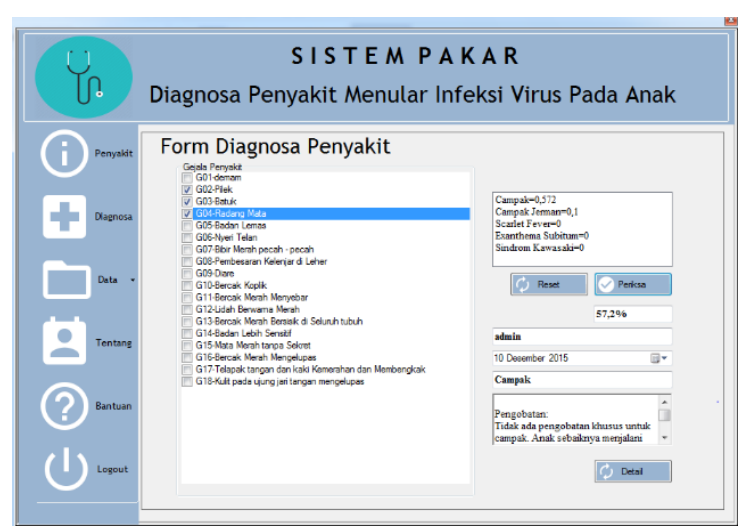

Fig. 9. Diagnosis page

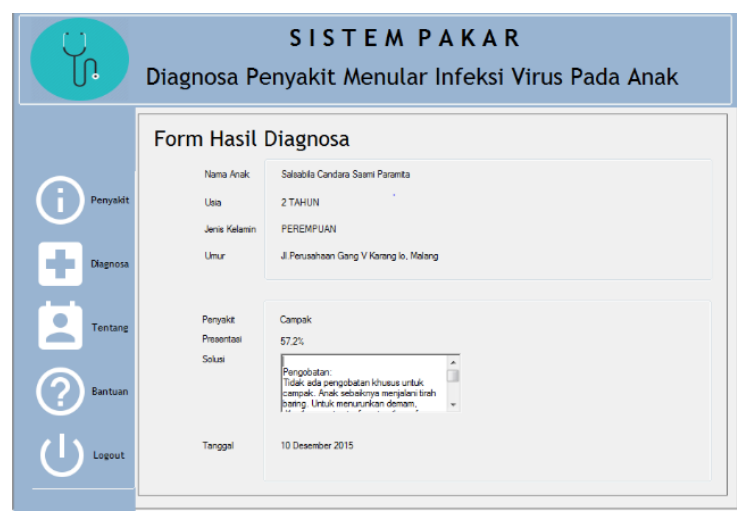

Fig. 10. Diagnosis results page 


\section{Testing}

Testing the system by comparing manual calculations with program calculations. For Measles Disease by taking the symptoms of Eye Inflammation with an $\mathrm{MB}$ value $[\mathrm{h}, \mathrm{e} 1]=0.8$ and the MD value $[\mathrm{h}, \mathrm{e} 1]=0.2$, then the calculation is:

CF [Campak, Radang Mata]

$\mathrm{MB}\left[\mathrm{h}, \mathrm{e}_{1}\right]-\mathrm{MD}\left[\mathrm{h}, \mathrm{e}_{1}\right]$

$=0,8-0,2$

$$
=0,6
$$

Application view is shown in Figure 11.

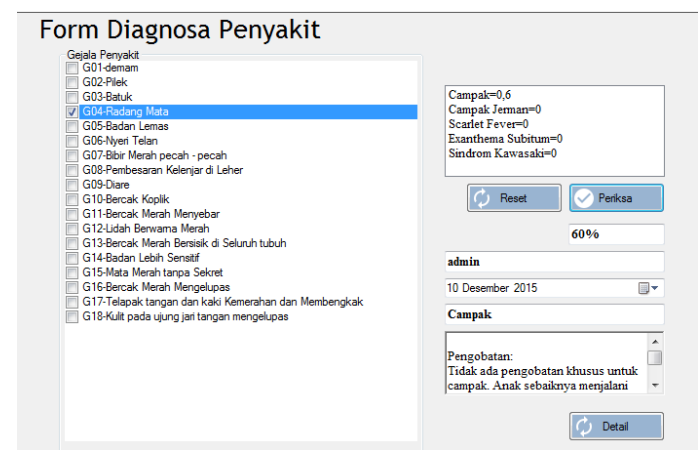

Fig. 11. Application view

System testing by counting two symptoms for one disease. For example by taking measles, with symptoms of inflammation of the eye with $\mathrm{MB}$ values $[\mathrm{h}, \mathrm{e} 1]=0.8$ and $\mathrm{MD}[\mathrm{h}, \mathrm{e} 1]=0.2$, and patches of $\mathrm{MB}$ copy $[\mathrm{h}, \mathrm{e} 2]=$ 0.9 and $\mathrm{MD}[\mathrm{h}, \mathrm{e} 2]=0.1$, then the calculation is:

MB [Campak, radang mata, bercak koplik]

$\mathrm{MB}\left[\mathrm{h}, \mathrm{e}_{1}\right]$ : Radang Mata

MB [h, e 2 ] : Bercak Koplik

$\operatorname{MB}\left[\mathrm{h}, \mathrm{e}_{1}\right]+\mathrm{MB}\left[\mathrm{h}, \mathrm{e}_{2}\right]^{*}\left(1-\mathrm{MB}\left[\mathrm{h}, \mathrm{e}_{1}\right]\right)$

$=0,8+0,9 *(1-0,8)$

$=0,8+0,9 *(0,2)$

$=0,8+0,18$

$=0,98$

MD [Campak, radang mata, bercak koplik]

MD [h, $\left.\mathrm{e}_{1}\right]$ : Radang Mata

MD [h, $\left.\mathrm{e}_{2}\right]$ : Bercak Koplik

$\operatorname{MD}\left[\mathrm{h}, \mathrm{e}_{1}\right]+\mathrm{MD}\left[\mathrm{h}, \mathrm{e}_{2}\right]^{*}\left(1-\mathrm{MD}\left[\mathrm{h}, \mathrm{e}_{1}\right]\right)$

$=0,2+0,1 *(1-0,2)$

$=0,2+0,1 *(0,8)$

$=0,2+0,08$

$=0,28$

CF [Exim, kulit berwarna kemerahan, kulit kering]

$$
\begin{aligned}
\mathrm{CF} & =\mathrm{MB}-\mathrm{MD} \\
& =0,98-0,28 \\
& =0,7
\end{aligned}
$$

The program result is shown in Figure 12. 


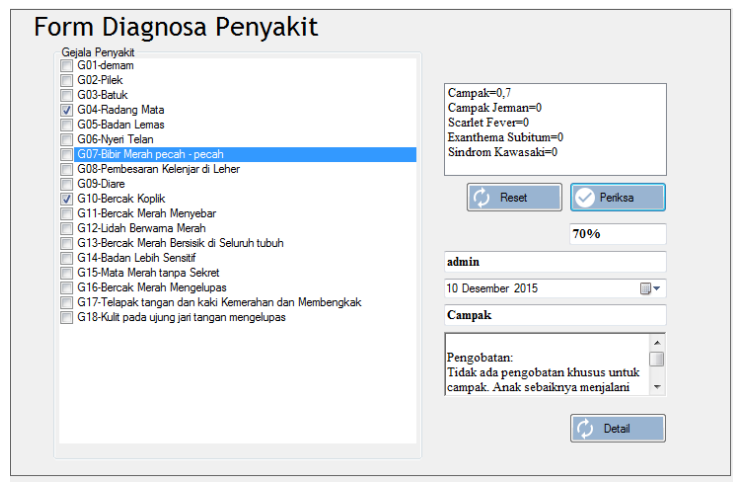

Fig. 12. The page results from two symptoms for a disease

Based on the display above, it can be seen that the app is veasy to use and user-friendly to diagnose a disease the children. Testing on the user of the expert system application is based on several questions about the application of expert systems to diagnose infectious viral infections in children. Recapitulation of the results of the assessment of 10 respondents 4 of whom were midwifery, nursing, and medical students as shown in Table 1 .

TABLE 1 USER TESTING OF EXPERT SYSTEMS

\begin{tabular}{llcccc}
\hline \multirow{2}{*}{ No } & \multirow{2}{*}{ Question } & \multicolumn{4}{c}{ Marking (\%) } \\
\cline { 3 - 6 } & & SB & B & KB & TB \\
\hline 1 & Content & $60 \%$ & $40 \%$ & $0 \%$ & $0 \%$ \\
2 & Uses & $60 \%$ & $40 \%$ & $0 \%$ & $0 \%$ \\
3 & Quality & $40 \%$ & $40 \%$ & $20 \%$ & $0 \%$ \\
4 & Interaction & $30 \%$ & $50 \%$ & $20 \%$ & $0 \%$ \\
\hline
\end{tabular}

\section{CONCLUSION}

The expert system application can be a medium of information on capabilities, knowledge, and facilities (based on symptoms or complaints) for cloud people in diagnosing viral infections in children. The application of this expert system uses the certainty factor method that provides a level of trust in the results of the diagnoses of diseases suffered by users. The output from this expert system is not the result of the user's disease diagnosis. The output of this expert system can be used as input or advice for medical experts. The final decision about a patient's illness is the authority of a medical expert. Results from manual calculations from the certainty factor method are the same as the results of expert system applications.

\section{REFERENCES}

[1] T. Astutik, "Sistem Pakar Untuk Mendiagnosa Penyakit Alopesia Pada Manusia," Malang Univ. Islam Negeri Maulana Malik Ibrahim Malang, 2009.

[2] F. F. Rohman and A. Fauzijah, "Rancang bangun aplikasi sistem pakar untuk menentukan jenis gangguan perkembangan pada anak," J. Fak. Huk. UII, vol. 6, no. 1, 2008.

[3] R. Rosnelly and U. P. Utama, Sistem Pakar: Konsep dan Teori. Penerbit Andi, 2012.

[4] S. Kusrini, "Sistem Pakar Teori dan Aplikasi," Penerbit Andi Yogyakarta, 2006.

[5] Khomsah. Desember. 2007, Penyakit Menular dan Penyakit tidak menular.(http://www.infopenyakit.com/2007/12/penyakit-menular-dantidak-menular.html) 